\title{
外形と空間構成と動線を考慮した戦後日本の各種建築物の平面特性 FLOOR PLAN CHARACTERISTIC OF VARIOUS BUILDINGS IN CONSIDERATION OF OUTLINE, ZONE, AND PATH IN JAPAN AFTER WORLD WAR II
}

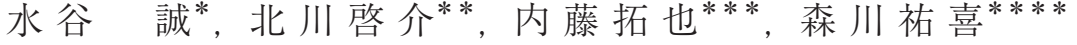 \\ Makoto MIZUTANI, Keisuke KITAGAWA, Takuya NAITO \\ and Yuki MORIKAWA
}

\begin{abstract}
Architectural space is composed by the interrelationship of three elements; relationship between interior space and exterior space which created the space by putting the wall, relationship between interior space and interior space which is based on arrangement and expanse of room and wall and human being who enjoy two relationships and move in it. So to speak, the architectural design is pursuit of the interrelationship of three elements, and what were created by the behavior are the outline, zone, and path. On this research, we define three kind of factor, outline which expanse to exterior space, zone, which means continuity of rooms and path which means positioning of various buildings. Furthermore, we analyze by comparison of those factors and consider the interrelationship of three elements.
\end{abstract}

Keywords : floor plan characteristic, out line, zone, pass, various buildings 平面特性, 外形, 空間構成, 動線, 各種建築物

\section{1.はじめに}

建築とは関係を創出するものであり，関係の集合体といっても過言 ではない。建築は，開く・閉じる，採り込む・遮るなどの関係により 外部と内部の 2 つの領域をつくりだし，そこに多様な関係が形成され る。中でも, 屋根や壁等を置くことによって生じる外と内の関係や内 部空間の内壁等により生じる内と内の関係は，建築において最も根源 的な関係である。更に，建築はその中に人を内包し，人がそこで様々 な活動を行うことにより，建築には機能が備わり，建築は成立してい るといえる。このように外と内の関係に人の活動を加えた，3つの要 素により建築は決定され，その結果として創出されたものが，外形， 空間構成，動線であるといえる。建築を計画する際に，必然的にこれ ら 3 つの視点が考慮されているといえる。

筆者らはこれまで，建築物の外形，空間構成，動線の 3 つの視点に 着目し，建築物の平面特性を新たな知見から示してきた。壁長と室面 積を考慮した建築物の平面特性の記述評価を探るため, 壁の長さと室 の大きさに関わる指標を定義し，近代住宅作品を対象とし，建築物と 空間をそれぞれ害体と虚体として捉えた研究 ${ }^{1)}$ を行ってきた。また， この前稿として, 建築平面における外形, 空間構成, 動線の 3 つの特 徵を定量的に測定し, 近代住宅作品における平面計画の傾向とその変
遷について論じてきた ${ }^{2)}$ 。さらに，これまでのビルディング・タイプ とは異なる新たな知見を示した研究として, 国内の各種建築物を対象 とした建築空間を，使用者の活動範囲，空間構成の関係に着目し，建 築空間を使用者の活動範囲の重なりの違いから専有と共有に区分さ れるとし, 専有領域と共有領域の視点から, その領域構成を明らかに した研究 ${ }^{3)}$ が挙げられる。また, この続稿として, 使用者の活動や活 動性質, 活動圈距離に着目寸ることで, 用途に対して横断的に領域構

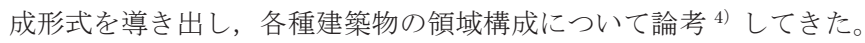

本稿では，人が水平面上における活動の特徵として，外形を外部と 内部の凹凸や伸長による建築平面の輪郭とし，空間構成を内部の室の 配置と壁の広がりと捉え，これらを建築平面の空間構成の仕方として 位置付けた。そこに動線という，人が建築平面上でどのように活動す るかに着目することで，本稿は，ひとつの建築平面の可能性を追求し ていこうとするものである。そこで，まず建築平面を手掛かりに，外 形，空間構成，動線の 3 つの特徴を定量化することにより建築物の平 面構成を分析するという前稿と同じ方針をとる。外形，空間構成，動 線の 3 つの特徵により導き出された平面構成の特徵を平面特性とし, これまでのビルディング・タイプを横断的に捉えることで, 各種建築 物に潜在的に存在する平面特性を明らかにすることを目的とする。

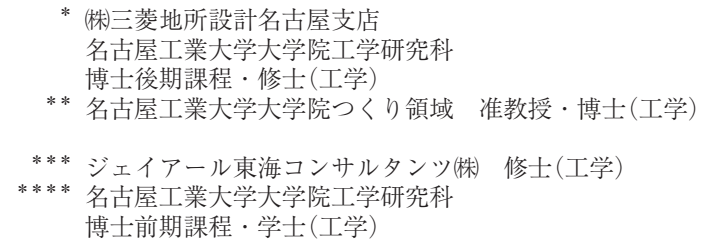

(株三菱地所設計名古屋支店

博士後期課程 · 修士 (工学)

* ジェイアール東海コンサルタンツ株) 修士(工学)

博士前期課程 · 学士 (工学)

Mitsubishi Jisho Sekkei Inc., Master of Engineering

Doctor Course Student, Graduate School of Engineering, Nagoya Institute of Technology, Master of Engineering

Assoc. Prof., Tsukuri College, Graduate School of Engineering, Nagoya Institute of Technology, Doctor of Engineering

JR Central Consultants Company, Master of Engineering

Master Course Student, Graduate School of Engineering, Nagoya Institute of Technology, Bachelor of Engineering 


\section{2. 既往の研究}

これまで，建築物における機能や用途，ビルディング・タイプを扱 った研究としては, 小川や坂本らによる建築内外に関する構成的性格 を捉えることにより新たなビルディング・タイプを明らかにしようと した研究 ${ }^{5-9)}$ が挙げられる。これらの研究は, 公共文化施設やアトリ ウム建築，都市型中高層建築などを対象として，これらの内部構成及 び形態構成を内部と外部を同時に把握しうる架構によるヴオリュー ムの空間単位に固有な性格を通して検討を行うことで，これらを内部 のみによる表現，内部と外部の独立した表現，内部と外部の関係によ る表現の 3 つ建築内外における構成的性格により位置付けている。

また，中井や坂本らは，建築物の外形のヴォリュームの着目し，建 築物の構成形式を明らかにしてきた。これらの研究として, 外形を立 体的な集合体として捉え, 外形の構成パタンと空間構成, 用途の切り 分けとの関係から市庁舎建築の構成形式を明らかにした研究 ${ }^{10)}$ や各 種用途建築における内部の室の集合と外形上のヴオリュームとの関 係から建築物の構成形式を明らかにした研究 ${ }^{11)}$ が挙げられる。さら に柱や壁などの配置による架構と空間構成との関係から建築物の構 成形式を明らかにした研究 ${ }^{12)}$ や外形構成と立地環境, 及び内部の用 途との関係から構成形式を明らかにした研究 ${ }^{13)}$ が行なわれてきた。

上記の研究は, 架構による構成的な性格に着目し, 建築内外に関す る構成的性格を捉えることにより，新たなビルディング・タイプを明 らかにした研究や外形ヴォリュームに着目し, 空間や室の分節などの 空間構成との関係から，建築物の構成形式を明らかにしている。これ らの研究は, 主に外形, 空間構成に分析の比重を置いているのに対し, 本稿は, 外形, 空間構成を建築平面の空間構成の仕方として位置付け,

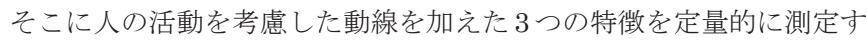
ることで, 各種建築物に潜在的に存在する平面特性を明らかにすると いう点において，異なる立場をとっている。

\section{3. 研究の流れ}

研究の流れを段階的に示す。

1）『建築設計資料集成』14-25) , 『新建築』26)，『建築文化』 ${ }^{27)} の 3$ 誌に共通して掲載された作品を対象作品注 1) とし, 『建築設計資料 集成』に掲載された平面図全てを対象事例注2)として選出する。

2）各種建築物の平面図の構成を定量的に分析していく上で, 一続き の壁の直線が終結するまでを<壁 $>$, 複数の<壁 $>$ によ内包さ れた領域をく室＞として定義する。

3）さらに外形, 空間構成, 動線の 3 つの特徴を定義し, それらを定 量化するために, 各対象作品の平面図から全ての外壁の長さ, <壁 >の数, 延床面積, <室>の数, 動線の長さを定量的に測定 する。

4） 3）で測定して得られたデータを基に，外形，空間構成，動線に おけるそれぞれの特徴を数值として算出する。

5） 4）で得られたデータを基に外形と空間構成に関する散布図，空 間構成と動線に関する散布図, 動線と外形に関する散布図を作成 し, クラスター分析を行い, それぞれの特徵における平面構成の 傾向について，考察する。

6）それらの平面構成における特徵の組み合わせから外形, 空間構成, 動線を類型化し, 各類型における平面特性から各種建築物間の関 係について探る。

\section{4. 平面の分析方法}

外形，空間構成，動線を考慮した建築平面の分析方法を示す。

1）平面図の構成を分析していく上で，まず外形をくアウトライン> 空間構成をくゾーン>，動線をくパス>として，それぞれ以下の ように定義する。(図 1 )

くアウトライン > : 建築物の外壁によって形取られた面の輪郭 くゾーン> : 建築物内部の室と壁の配置と広がり くパス $>$ : 建築物内部の人の動きを模擬化した線

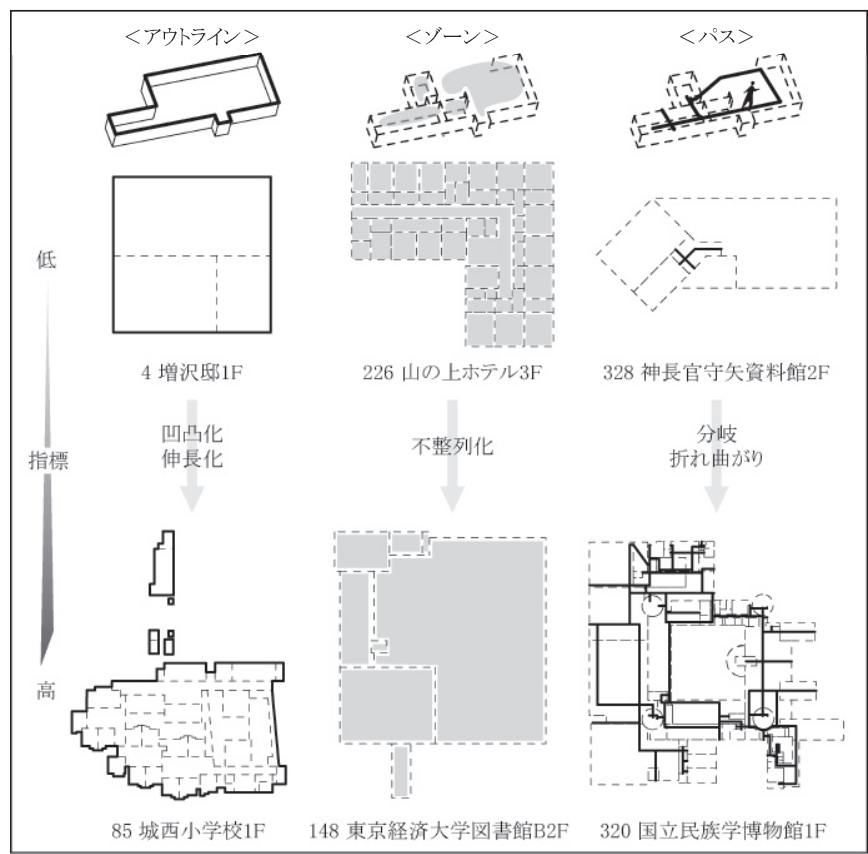

図 1 <アウトライン >, <ゾーン>，＜パス>の定義と指標

2）対象とする 185 作品，440 事例の平面図から全ての外壁の長さ, <壁>注 3) の数, 各階床面積, <室> 注 4) の数, 動線の長さ注 5) を定量的に測定する。測定結果を指標の(1)，(2)，(3)に代入し， それぞれ算出する。また，以下に上図の事例を対象にそれぞれ定 量的に測定し，〈アウトライン>，〈ゾーン>，〈パス〉をそれ ぞれ算出したものを示した（表 1 ）。

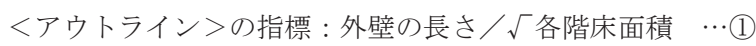

<ゾーン>の指標 ：<壁 $>$ 数 $/<$ 室 $>$ 数 $\quad \cdots(2)$

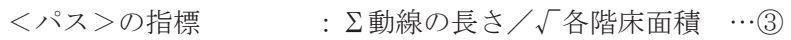

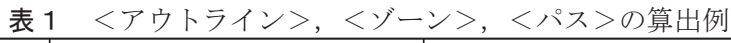

\begin{tabular}{|c|c|c|c|c|c|c|}
\hline \multirow{3}{*}{ アウトライン } & \multicolumn{3}{|c|}{4 增沢邸1F } & \multicolumn{3}{|c|}{85 城西小学校 $1 \mathrm{~F}$} \\
\hline & 外壁の長さ & $\mid \sqrt{\text { 各階床面稹 }}$ & アウトライン & 外壁の長さ & 名階床面䅡 & アウトライン \\
\hline & $21.6 \mathrm{~m}$ & $\sqrt{29.1 \mathrm{~m}^{2}}$ & 4.0 & $752.6 \mathrm{~m}$ & $\sqrt{4480.9 \mathrm{~m}^{2}}$ & 11.2 \\
\hline \multirow{3}{*}{ ゾーン } & \multicolumn{3}{|c|}{226 山の上ホテル $3 F$} & \multicolumn{3}{|c|}{148 東京経済大学图書館B2F } \\
\hline & <壁>の数 & <室>の数 & ジーン & <壁>の数 & <室>の数 & ゾーン \\
\hline & 57.0 & 48.0 & 1.1 & 49.0 & 15.0 & 3.2 \\
\hline \multirow{3}{*}{ パス } & \multicolumn{3}{|c|}{328 神長官守矢資料館 $2 \mathrm{~F}$} & \multicolumn{3}{|c|}{320 国立民族学博物館 $1 F$} \\
\hline & 動線の死さ & 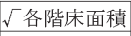 & パス & $\sum$ 動線の辰さ & $\sqrt{ }$ 各階床面櫴 & パス \\
\hline & $6.0 \mathrm{~m}$ & $\sqrt{ } 131.0 \mathrm{~m}^{2}$ & 0.5 & $1168.0 \mathrm{~m}$ & $\sqrt{ } 10319.6 \mathrm{~m}^{2}$ & 11.4 \\
\hline
\end{tabular}

3） 以上のデータを基に, 縦軸をくアウトライン >の指標, 横軸を くゾーン>の指標として, 全対象作品をプロットし, 散布図を作 成する。同様に, 縦軸をくゾーン>の指標, 横軸をくパス $>$ の指 標とした散布図, 縦軸をくパス $>$ の指標, 横軸をくアウトライ ン>の指標とした散布図を作成する。 


\section{5. 各型にみる各種建築物の平面構成}

各種建築物における平面構成の傾向を整理 するために, クラスター分析を行った。クラス ター分析を行うために，〈アウトライン>と 〈ゾーン $\rangle,\langle$ 〈゙ーン $\rangle$ と<パス $\rangle$, 〈パス $>$ とくアウトライン >のそれぞれを軸とし, 各指 標をもとに, 固有值と寄与率を求め, この寄与 率により, 平面構成の傾向を整理した。ここで は，定義したくアウトライン>，〈ゾーン>， くパス>の指標をそれぞれ組み合わせること により，建築平面を構成する上で，外形，空間 構成, 動線が平面構成の特徵として, それぞれ どのような相関がみられるかを明らかにする。

くアウトライン $>$ と<ゾーン >の散布図で は，これらの指標を基に，固有值と寄与率を求 め, その寄与率により判断した結果, 平面構成 において $\mathrm{A}$ 一Gの 7 つに分類された（図 2)。 これらの指標の組み合わせ,つまり外形の凹凸 や伸長の度合いと室の配置の整列性に着目寸 ることで, 主に建築平面全体の空間構成がどの ように形成され，建築平面の特徵として，現れ ているかを明らかにする。

$\mathrm{A}$ 型は, くゾーン>の指標が非常に低く, 主 ＜室＞をもたず,小さな＜室＞を廊下に沿って 整列させて複製する構成となっている。B型は, <アウトライン>の指標, <ゾーン>の指標共 に非常に低く, 方形の外形の中を分割して <室＞が形成されており，主＜室＞に沿って小 さなく室＞を整列して配置する構成となって いる。 $\mathrm{C}$ 型は, <アウトライン>の指標, くゾ ーン>の指標共に低く, 大きな $<$ 室 $>$, 小さな ＜室＞を共に等価に扱い,それらを連結する構 成となっている。 $\mathrm{D}$ 型はくアアウトライン >の指 標，くゾーン>の指標が高くなっており，1つ の大きな<室 $>$ にさな＜室 $>$ を内包, あるい は付属的に配置する構成となっている。 $\mathrm{E}$ 型は, くアウトライン>の指標が高く, <ゾーン >の 指標が低くなっており，整列して配置した ＜室＞群をある点を中心として放射状に配置 した構成となっている。 $\mathrm{F}$ 型は，＜アウトライ ン>の指標, <ゾーン>の指標共に高く, <室＞群を連結する構成となっている。G 型は, <アウトライン>の指標, <ゾーン>の指標共 に非常に高く, <室 >と<室 >との距離を離し て配置し,通路により繋げる分棟型の構成とな っている。

<ゾーン $>$ と<パス $>$ 散布図では, これら の指標を基に, 固有值と寄与率を求め, その寄 与率により判断した結果, 平面構成において a 一e 5 つに分類された（図 3 ）。これらの指

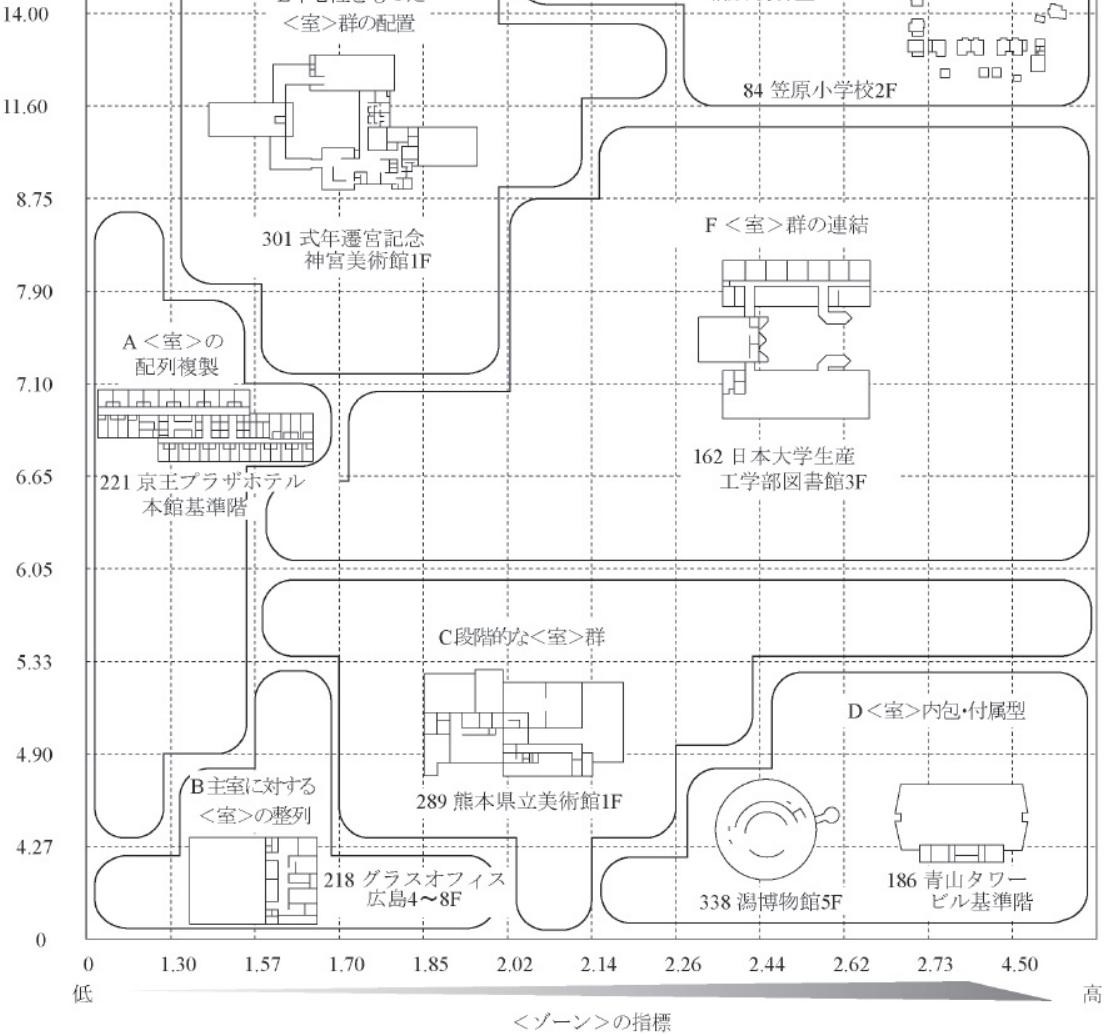

図 2 ＜アウトライン>と<ゾーン>における散布図

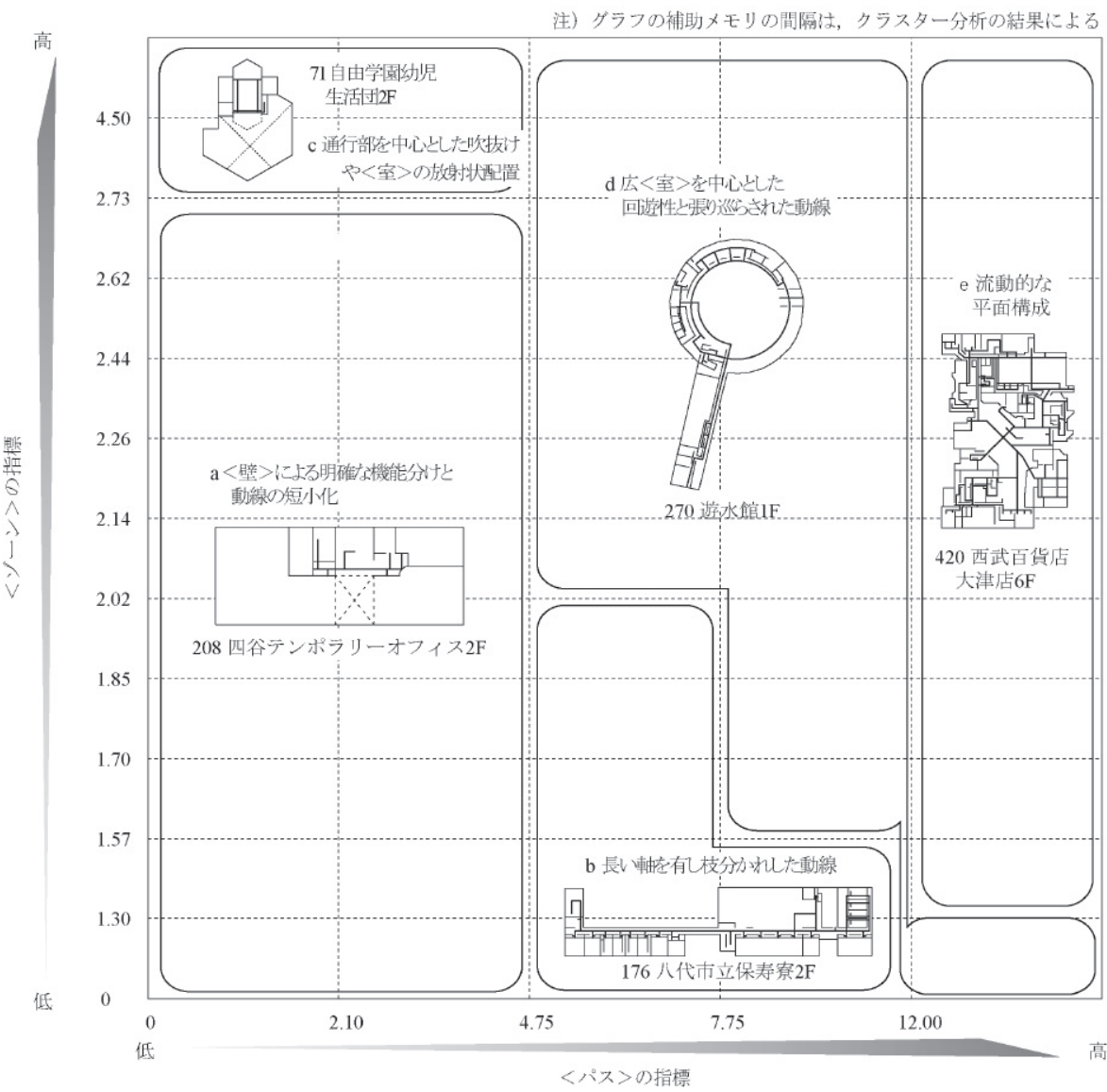

図 $3<$ ぐーン>と<パス>における散布図 


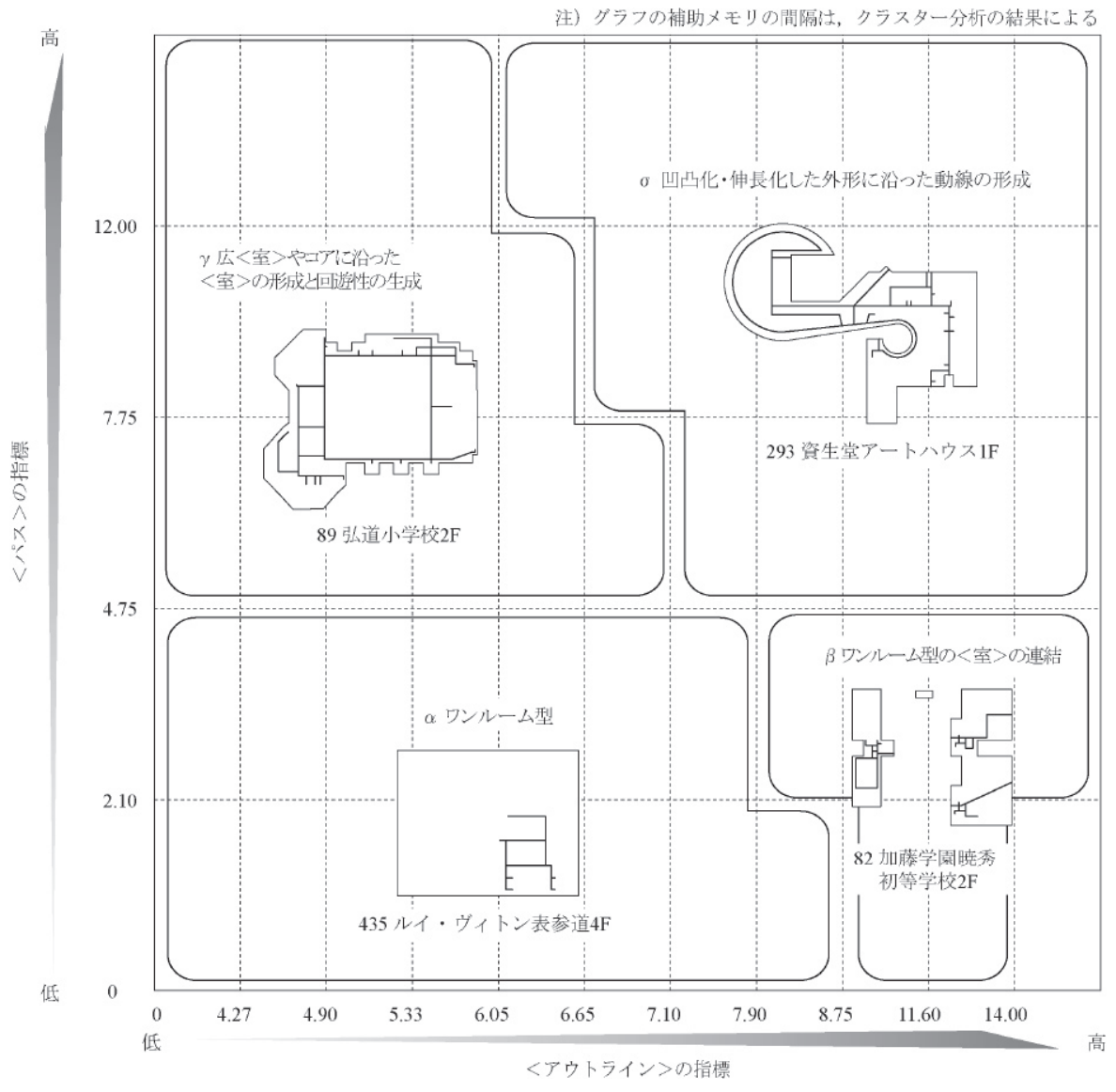

図4＜パス>と<アウトライン $>$ における散布図
コアを中心として, テラスやアプローチ等の外 部空間との接点やく室 >を周囲に配置し, 動線 に回遊性をもたせた構成となっている。 $\sigma$ 型は, <パス>の指標, <アウトライン>の指標共に 高く, 凹凸化や伸長化した外形に沿って動線を 形成させた構成となっている。

\section{6. 各類型にみる各種建築物の平面特性}

指標毎の平面計画における対象事例の散布 図の傾向から，16 の型が明らかとなった。結 果として，この 16 の型の組み合わせから，各 種建築物は 32 の類型が得られた (表 2 )。 各 類型における平面特性から各種建築物間の関 係について特徴的なものを以下に述べる。

$\mathrm{A}-\mathrm{a}-\alpha$ の平面特性として, ワンルーム型の <室>が配列複製的に配置され, 壁による明確 な機能が分割され, それにより動線が短小化さ れていることが挙げられる。また, この類型は 9 事例確認され，これらのうち 3 事例が美術館 であり, 平面特性と用途の間に相関がみられた。 美術館以外の用途として集合住宅，病院，ホテ ル，博物館，劇場・ホールなどが確認された。 集合住宅において, 共用廊下から各住戸に繋が ることで, 室が効率的に配置され，動線を短く し,壁により明確に機能が分けられる平面構成
標の組み合わせ, つまり室の配置の整列性と人の活動に着目すること で，主に室の配置により動線がどのように生成され，それが建築平面 の特徴として現れているかを明らかにする。

$\mathrm{a}$ 型は, <ゾーン>の指標, <パス >の指標共に低く, 廊下や階段 等の通行の為の $<$ 室 $>$ と滞在する為の<室 $>$ が，＜壁 $>$ にって明確 に分割されたことによって動線の短い構成となっている。b型は, <ゾ ーン>の指標が低く，〈パス>の指標が高くなっており，一つの長い 軸をもった動線から枝分かれした構成となっている。c 型は，くゾー ン>の指標が高く, <パス >の指標が低くなっており, 廊下や階段の 通行の為の<室 $>$ を心として滞在する為の<室 $>$ や吹抜けが放射 状に配置された構成となっている。 $\mathrm{d}$ 型は，くゾーン>の指標，くパ ス >の指標共に高く, 大きな $<$ 室 $>$ を心に回遊性を持ち, そこから 付属的な<室>へと動線が張り巡らされた構成となっている。 $\mathrm{e}$ 型は, <パス>の指標が非常に高く, 平面全体が流動的な構成となっている。 <パス $>$ と<アウトライン>の散布図では, これらの指標を基に, 固有值と寄与率を求め, その寄与率により判断した結果, 平面構成に おいて $\alpha$ 一の 4 つに分類された（図 4 ）。これらの指標の組み合わ せ，つまり人の活動と外形の凹凸や伸長の度合いに着目することで, 主に外形により動線がどのように生成され，それが建築平面の特徵と して現れているかを明らかにする。

$\alpha$ 型は, <パス >の指標, <アウトライン>の指標共に低<, 大空 間を有したワンルーム型の構成となっている。 $\beta$ 型は，〈パス>の指 標が低く, <アウトライン>の指標が高くなっており, ワンルーム型 の<室 $>$ 群を集結させた構成となっている。 $\gamma$ 型は，〈パス >の指標 が高く, <アウトライン>の指標が低くなっており, 大きな<室 $>$ や
がなされている。また, 病院において, 室を規則的に配置することで, 患者のプライバシーを保護し, 即座に患者に対するケアが行なえるよ うに患者と病院側のスタッフが滞在する室同士を明確に分け，動線を 短くすることを計画された平面構成がなされている。

$\mathrm{A}-\mathrm{b}-\gamma$ の平面特性として，広＜室 $>$ やコアに沿って<室 $>$ が配列 複製的に配置され, 通路又は廊下の基本となる軸から枝分かれした動 線により回遊性が生まれていることが挙げられる。また，この類型は 15 事例確認され，これらのうち大学とホテルがそれぞれ 3 事例ずつ みられ，平面特性と用途の間に相関がみられた。これらの用途以外に 大学, 病院, 事務所, ホテル, 体育館, 美術館, 博物館, 庁舎などが 確認された。事務所や庁舎において, 大きい<室>やコアを中心とし, そのコアから主要な通路を通り, 各事務所や会議室, または議員の控 え室へと繋がる平面構成がなされている。これは，ホテルにおける通 路から各宿泊室へと繋がる平面構成や大学における廊下から各教室 や研究室へと慗がる平面構成において類似がみられる。

$\mathrm{B}-\mathrm{a}-\alpha$ の平面特性として, 主室に対して<室 $>$ の配置を整列させ ることにより，明確に機能が分節され，動線が短小化されていること が挙げられる。また, この類型は 16 事例確認され, これらのうち 8 事例が戸建住宅であり，平面特性と用途の間に相関がみられた。戸建 住宅以外の用途として, 大学図書館, 事務所, 美術館, 博物館, 庁舎, 店舗などが確認された。主室の空間を，戸建住宅においては，居間や 食堂, 事務所では事務室やエントランスホール, 店舗では売場とし, それらに対して, 戸建住宅においては, 寝室や書斎, 事務所において は倉庫や会議室, 店舗においては, トイレや倉庫等が配置されている。 このようにワンルームを残しつつ, 壁により明確に機能を分け, 動線 
が短くなることを背景とし, 機能を明確に分節し, 付属的に室が配置 されたこれらの用途の平面構成において類似がみられる。

$\mathrm{C}-\mathrm{d}-\gamma$ の平面特性として, 広＜室>やコアを中心にその周辺に室 が配置され, 動線に回遊性が生まれていることが挙げられる。また, この類型は 45 事例確認され, これらのうち 8 事例が劇場・ホール, 7 事例が博物館であり，平面特性と用途の間にそれぞれ相関がみられた。 これらの用途以外に幼稚園, 小学校, 大学, 公立図書館, 大学図書館, 事務所, 旅館, 体育館, 美術館, 庁舎, 集会施設, 工場などが確認さ れた。広く室>やコアとなる室は, 劇場・ホールにおいては舞台や客 席, 奈落であり, 博物館においては常設展示室や収蔵庫, 記念ホール となり, これらを中心に，他の室が配置され，それらに沿うように動 線がつくられているため, 回遊性が生まれている。

$\mathrm{D}-\mathrm{d}-\gamma$ の平面特性として, 室が，広＜室>やコアを中心に，付属 的に配置され，動線もそれに沿うように張り巡らされているため，回 遊性が生まれていることが挙げられる。また，この類型は 37 事例確 認され, これらのうち 9 事例が劇場・ホール, 大学図書館と事務所が それぞれ 6 事例ずつみられ，平面特性と用途の間にそれぞれ相関がみ られた。これらの用途以外に幼稚園, 小学校, 大学, ホテル, 旅館, 体育館, 競技場, 博物館, 庁舎, 集会施設, 店舗などが確認された。 広＜室>やコアとなる室は, 劇場・ホールにおいては, 奈落やホワイ エ，大学図書館においては，視聴覚室や開架閲覧室，事務所において は，上下階を移動するエレベータであり，これらを中心に機械室や事 務室, ゼミ室等の室が付属的に配置されている。

$\mathrm{E}-\mathrm{e}-\sigma$ の平面特性として，中心性を持ったく室＞が群を成すよう に配置され，外形が，凹凸化・伸長化されることにより，動線が流動 的な平面が形成されることが挙げられる。また, この類型は 7 事例確 認され，これらのうちホテルと美術館がそれぞれ 2 事例ずつみられ， 平面特性と用途の間にそれぞれ相関がみられた。これらの用途以外に, 集合住宅, 庁舎, 劇場・ホールなどが確認された。中心性を持つく室 $>$ として，ホテルにおいては宴会場やホワイエ，オリエンテーションホ 一ル，美術館においては企画・公募展示室やアトリエであり，これら を不整形に配置させることにより，流動的な平面となっている。

$\mathrm{E}-\mathrm{b}-\sigma$ の平面特性として，＜室>の集合が中心となり，その室や 凹凸化もしくは伸長化した外形に沿うように動線が，形成されること が挙げられる。また, この類型は 22 事例確認され，これらのうち 5 事例が集合住宅，4 事例が美術館であり，平面特性と用途の間にそれ ぞれ相関がみられた。これらの用途以外に幼稚園, 中学校, 高校, 公 立図書館，事務所，ホテル，庁舎，集会施設などが確認された。集合 住宅において，中心となる中庭や子供の遊び場などに沿うように共用 廊下が設けられ，そこから枝分かれした廊下の先に各住戸がそれぞれ 配置される平面構成がなされている。また中学校において, 中庭を中 心とし, 廊下を通じて各教室や調理室, 図書館, 職員室などが不整列 に配置された平面構成がなされている。

$\mathrm{E}-\mathrm{d}-\sigma$ の平面特性として, 広 $<$ 室 $>$ や $<$ 室 $>$ 群を中心とした配置 がなされ，外形がロ凸化・伸長化されることにより，動線が各室へと 張り巡らされ, 回遊性が生まれていることが挙げられる。また, この 類型は 14 事例確認され，これらのうち 3 事例が集合住宅であり，平 面特性と用途の間に相関がみられた。集合住宅以外の用途として中学 校，図書館，福祉施設，ホテル，旅館，美術館，博物館，庁舎などが 確認された。児童福祉施設においては保育室, 集合住宅においてはリ
ビング, 博物館においては中庭を中心に動線における回遊性がみられ た。また，目的に合わせた大きさの<室 >を中心に回遊性をもたせる ことによって, その中心に滞留空間を形成する。この類型は, 人々の 意識を回遊性のある＜室>の中心に向けることにより，児童の安全性 の確保を図る目的が背景としてあらわれ，中心となる<室>と対比的 に, 個の空間がつくり出され, 中心から外周へ向かって, 静から動, 動から静の性質へのヒエラルキーをもった空間を形成するものとし てこれらの用途における平面構成との類似がみられる。

$\mathrm{F}-\mathrm{d}-\gamma$ の平面特性として, 連結された室の集合体が配置され, こ の<室 $>$ 群や広<室>, コアを中心に回遊性を持った動線が形成され ることが挙げられる。また, この類型は 25 事例確認され, これらの うち公立図書館と事務所, 集会施設がそれぞれ 3 事例ずつみられ, 平 面特性と用途の間に相関がみられた。これらの用途以外に戸建住宅, 大学, 大学図書館, 病院, 福祉施設, 体育館, 美術館, 劇場・ホール, 店舗などが確認された。公立図書館や大学図書館において, 書庫や開 架閲覧室，学習室，吹き抜け空間等の広＜室＞を中心とした室の集合 により平面構成がなされている。これは，福祉施設における吹抜けを 中心として, 休養室や宿泊室, リハビリルームなどの室が配置される 平面構成や集会施設におけるロビーやエントランスを中心に，集会室， 会議室が配置される平面構成との類似がみられた。

$\mathrm{F}-\mathrm{d}-\sigma$ の平面特性として, 広＜室＞を中心にその周辺に<室 $>$ が 連結するように配置されることにより, 外形が凹凸化・伸長化し, 動 線が形成されていることが挙げられる。また, この類型は 33 事例確 認され，これらのうち 5 事例が中学校であり，平面特性と用途の間に 相関がみられた。中学校以外の用途として集合住宅, 小学校, 高校, 大学, 大学図書館, 病院, 福祉施設, 事務所, ホテル, 旅館, 競技場, 体育館, 美術館, 博物館, 庁舎, 劇場・ホールなどが確認された。小 学校や中学校, 高校における各教室や理科室, 技術室などの特別教室, 事務所におけるロビーや玄関ホール，事務室，機械室等がそれぞれ不 整列に配置されることにより, 平面全体が凹凸化・伸長化し, 動線が 形成されている平面構成に類似がみられる。

$\mathrm{E}-\mathrm{e}-\sigma$ の平面特性として, 通行部を中心とした吹き抜けやく室 $>$ 群が連なり, それらが放射線状に配置されていることや＜室 > 群の連 なりが一つの空間の中に配置されていることが挙げられる。また, こ の類型は 7 事例確認され，これらのうち 3 事例が戸建住宅であり，平 面特性と用途の間に相関がみられた。戸建住宅以外の用途として幼稚 園, 中学, 福祉施設, 集会施設などが確認された。戸建住宅において, 居間や食堂, 書斎, 寝室などの<室 $>$ が連なり, 福祉施設においては, 大きなワンルームの中に，居住室や病室，管理室などの＜室 $>$ が連な るように配置され，平面構成に類似がみられる。

$\mathrm{G}-\mathrm{d}-\sigma$ の平面特性として, 広＜室>を中心に各室が配置され，同 時に室同士に距離をもたせた分棟型とすることで，外形が凹凸化・伸 長化し, 動線に回遊性が生成されることが挙げられる。また, この類 型は 12 事例確認され, これらのうち 6 事例が小学校であり, 平面特 性と用途の間に相関がみられた。小学校以外の用途として幼稚園, 中 学校, 高校, 旅館, 美術館などが確認された。小学校や中学校におい て,ゆとりをもって計画された共用廊下を中心に各教室が配置された 平面構成がなされている。また旅館において, ロビーを中心とし, 庭 などの外部空間を鑑賞できる回遊性をもった動線により各宿泊室へ と繋がる平面構成がなされている。 
表 2 各類型における各種建築物

\begin{tabular}{|c|c|c|}
\hline -么型) & & \\
\hline 建築名 & 䨖主 & 用江 \\
\hline -3代官山ヒルサイドララス $(3 \mathrm{~F})$ & 1969 & 集合隹宅 \\
\hline 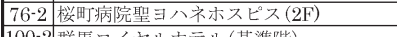 & 1994 & \\
\hline 0-2群馬ロイヤルホテル(基淮階) & & \\
\hline & & 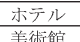 \\
\hline 1-11 群馬県立近代美術館·歴史博物馆( 地 & & 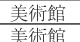 \\
\hline 签原史料館 $(2 \mathrm{~F})$ & & 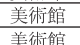 \\
\hline $\begin{array}{l}\text { 7-2-2 } \\
9 \text { 群馬県立館林美術館 (2F) }\end{array}$ & & $\begin{array}{l}\text { 美術館 } \\
\text { 博物館 }\end{array}$ \\
\hline $\begin{array}{l}49-1 \text { 潟愽物館 (1F) } \\
8 \text { 8 } 1 \text { 東京文化会館 (B2F) }\end{array}$ & 1997 & 博物馆 \\
\hline 会館 (B2F) & 1961 & \\
\hline 珑と回 & & \\
\hline 建筑名 & 陖工年 & 用途 \\
\hline 3 金沢工業大学 本館 $(3 \mathrm{~F})$ & 1969 & \\
\hline :体育芸術專門学群中 & 197 & \\
\hline 体育芸術専門学 & 19 & \\
\hline 聖当八ネホスピ & 196 & 痌院 \\
\hline リフレ $(6 \mathrm{~F})$ & 195 & 事務所 \\
\hline 儿本館(基淮階) & 19 & \\
\hline 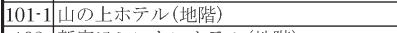 & & \\
\hline トトンホテル(地 & 1983 & 木产 \\
\hline 大学体育館 $(3 \mathrm{~F})$ & 1970 & 体育的 \\
\hline 弦一䭚郎現 $($ 代代美術館 & 1991 & 美術館 \\
\hline な加五美術直 & & 美術館 \\
\hline 4国立民 & & 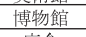 \\
\hline & & \\
\hline & & \\
\hline 䞱 (1) & & \\
\hline
\end{tabular}

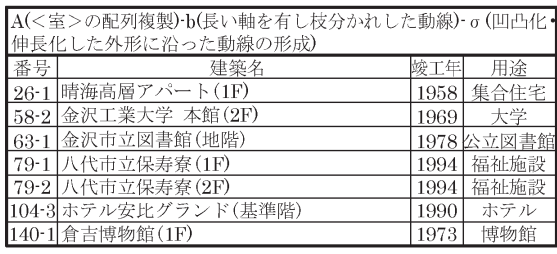

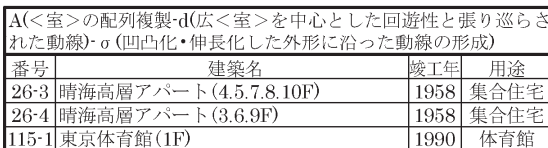

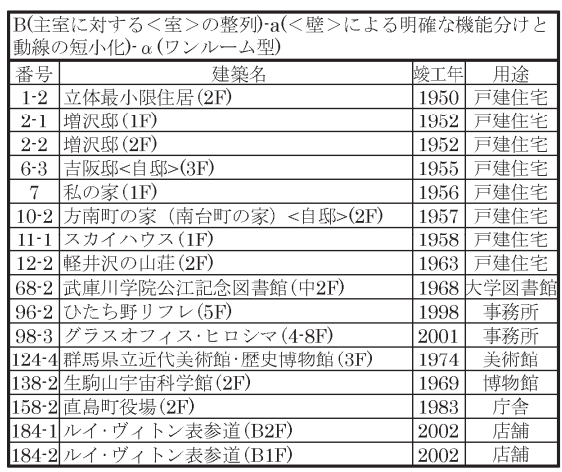

\begin{tabular}{|c|c|c|}
\hline 広く室〉やロアに涪 & & \\
\hline \begin{tabular}{l|c} 
番号 & 建筑名名 \\
\end{tabular} & 摭工年 & 用途 \\
\hline て未来大学 $(5 \mathrm{~F})$ & 2000 & \\
\hline 64-2 & & \\
\hline $68-4$ 武! & & \\
\hline \begin{tabular}{ll|l}
$4-2$ & 四 \\
\end{tabular} & 1990 & \\
\hline 3-2 & & \\
\hline $3-\left.4\right|^{\text {筑 }}$ & 1983 & \\
\hline $9-2$ 遊了 & 1997 & 競技萑 \\
\hline $6-1 / \Lambda 1$ & 1991 & 博物县 \\
\hline 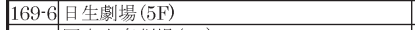 & 1963 & \\
\hline-3 国立文 & $1983 \cdot 15$ & 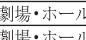 \\
\hline & & \\
\hline bされ & & \\
\hline 建筑名 & 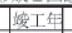 & 用是 \\
\hline 118 福岡ドーム (1F) & $1:$ & 競技場 \\
\hline & & \\
\hline 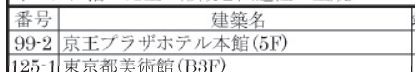 & $\frac{1971}{1975}$ & 衒 \\
\hline
\end{tabular}

\begin{tabular}{|c|c|c|}
\hline \multicolumn{3}{|c|}{ C(段階的なく室〉样)-a(壁〉による明確な機能分けと動線の } \\
\hline 建築名 & 庱工年 & 用途 \\
\hline \begin{tabular}{|l|l|}
$4-2$ & 有富邸 代々木の家 (2F) \\
\end{tabular} & 1953 & 巨建住宅 \\
\hline 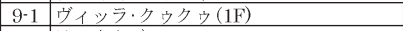 & 1957 & 巨建住宅 \\
\hline \begin{tabular}{|l|l|}
13 & 地の家 $(1 \mathrm{~F})$ \\
\end{tabular} & 1966 & 建住宅 \\
\hline \begin{tabular}{|l|l|}
$15-1$ & 住宅KAH(1F) \\
\end{tabular} & 1967 & 巨建住宅 \\
\hline $16-1$ 粟津邸 $(\mathrm{B} 2 \mathrm{~F})$ & & \\
\hline $22-2$ 南青山の家 $(2 \mathrm{~F})$ & 1981 & 揵住宅 \\
\hline 37-1我如り文化幼稚園(地階) & & \\
\hline $61-2$ 堺市立图書館 $($ 中 2 階) & 1971 & 公立国豐館 \\
\hline 67 不知火町立美術館·圆書館 (1F) & 1999 & 公立国書館 \\
\hline 69-2 東京経済大学図書館 (B1F) & 1968 & 大学戝書館 \\
\hline 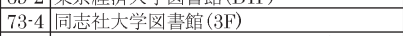 & 1973 & 大学图書领 \\
\hline $86-2$ 日本アイ・ビ・エム本社ビル $(2 \mathrm{~F})$ & 1971 & 事務所 \\
\hline 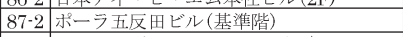 & 1971 & 事務所 \\
\hline 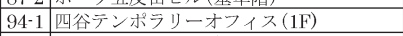 & 1990 & 事務所 \\
\hline \begin{tabular}{l|l}
$96-1$ & Uたち野リフレ(1F) \\
\end{tabular} & 1998 & 事務所 \\
\hline $97-1$ 読売広告社本社 (IF) & 2000 & 事務所 \\
\hline 97-2 谠売広告社本社 (3F) & 2000 & 事務所 \\
\hline 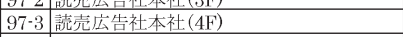 & 2000 & 事務所 \\
\hline $98-1$ グラスオフィス・ヒロシマ $(1 \mathrm{~F})$ & 2001 & 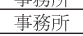 \\
\hline 106-2直島コンテンポ゙ラリーアートミュージアム(2F & & 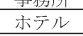 \\
\hline 111-1 日日本歯科大学体育館 (地階) & 1970 & 体育館 \\
\hline 111-2 日本藏科大学体育館 (1F) & 1970 & 体高館 \\
\hline 113-33藤沢市秋吉台文化体育館 (中2F) & 1984 & 体育館 \\
\hline 121-11遠山記念館付属美術館 $(1 \mathrm{~F})$ & 1970 & 美術館 \\
\hline 熊本県立美術館 (4F) & 1976 & 美術館 \\
\hline 飯田市小䇾原史料皿 & 1999 & 美術领 \\
\hline 代市立博物館·未来の森ミュージク & 1991 & 过物館 \\
\hline $149-55$ 渴博物館 $(7 \mathrm{~F})$ & 1997 & 博物館 \\
\hline 萩市庁含(中2階) & 1974 & \\
\hline $152-4$ 萩市庁舎 (中3階) & 1974 & \\
\hline $160-1$ 入来町罗童館 $(1 \mathrm{~F})$ & 1972 & 集会施設 \\
\hline - -2自石市情瓡 & 1997 & 集会施設 \\
\hline 168-2東京文 & & \\
\hline 171-3岩手県民会馆 (3F) & & 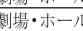 \\
\hline & 1995 & \\
\hline (1F) & & \\
\hline & & \\
\hline イ・ヴィト & & \\
\hline 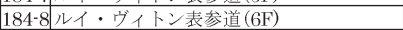 & 2002 & \\
\hline F) & 2002 & \\
\hline & & \\
\hline
\end{tabular}
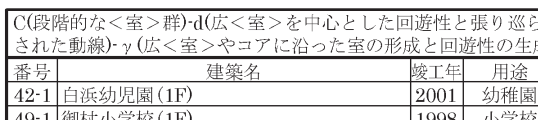

$42-1$ 白浜幼临園 $(1 \mathrm{~F})$

49-1 御杖小学校 $(1 \mathrm{~F})$

$56-1$ 国際聖マリア学院(地院)

\begin{tabular}{l}
$60-1$ 公立はこだて未来大学 $(1 \mathrm{~F})$ \\
\hline $61-1$ 堺市立图書館 $(1 \mathrm{~F})$
\end{tabular}

61-1.3

68-1 1 武庫川学院公江記念図書舵 $(1 F)$

68-3 武庫川学院公江記念図書館 $(2 \mathrm{~F})$

$71-2$ 東北大学付属中央图書館( $(\mathrm{F})$

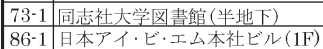

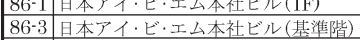

\begin{tabular}{l|l}
$88-1$ & 大同生命本社ビル $(1 \mathrm{~F})$ \\
\hline $92-1$ & 東京堂干代田ビル $(1 \mathrm{~F})$
\end{tabular}

92-2 東京堂千代田ビル(基淮階)

\begin{tabular}{l}
$108-1$ 掬水亭 $(1 \mathrm{~F})$ \\
\hline $110-2$
\end{tabular}

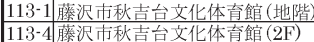

126-2熊本県立美術館 $(2 F)$

133 淺蔵五十吉美術館(1F)

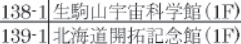

141 瀨戸内人海脴史民俗資料馆 $(1 \mathrm{~F})$

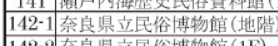

147-1 中原中也記念馆官本館 $(1 \mathrm{~F})$

148 新美南古記念館 (1F)

151-3神奈川県新宁合 $(6 \mathrm{~F})$

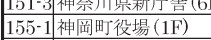

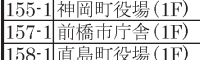

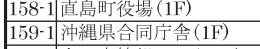

$167-3$ 白石市情報センター $(3 \mathrm{~F})$

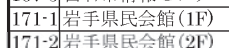

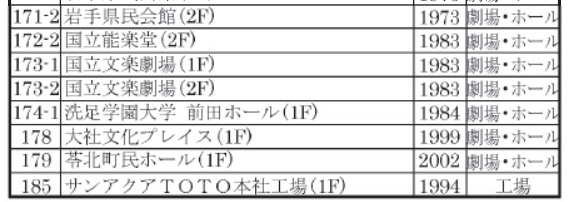

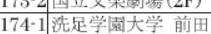

179 荟北町民ホール人(1)

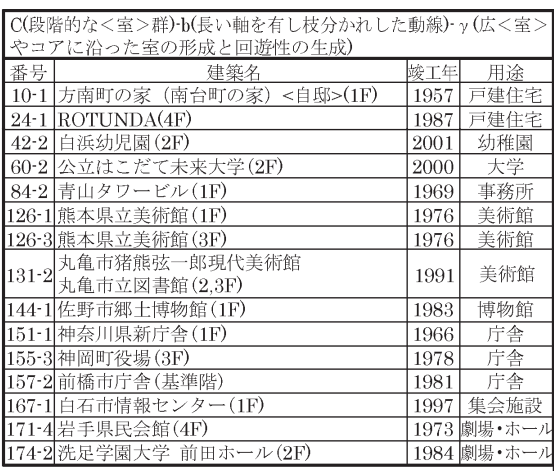

C(段階的なく宾〉群)-c(通行部を中心とした吹拔けやく室〉の放

\begin{tabular}{|c|c|c|}
\hline \begin{tabular}{l|l} 
番号 \\
\end{tabular} & 陵工年 & \\
\hline 17-2 住吉の長屋 (2F) & 1976 & 住宅 \\
\hline 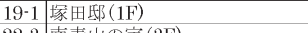 & 1980 & 住宅 \\
\hline $\begin{array}{l}22-3 \\
70-3\end{array}$ & 1981 & 住宅 \\
\hline 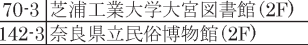 & & 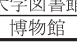 \\
\hline
\end{tabular}

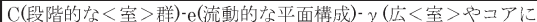

\begin{tabular}{|c|c|c|}
\hline 建第名 & 站工分 & 用途 \\
\hline 99-1 京王プラザホテル本館 $(3 \mathrm{~F})$ & 1971 & 木テル \\
\hline 116 酒田市国体記念体育馆 $(1 \mathrm{~F})$ & 1991 & 体育館 \\
\hline $\begin{array}{ll}117 & \text { 東京唇已国際水泳場(地階) } \\
\end{array}$ & 1993 & 競技場 \\
\hline 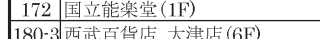 & 1983 & 矨場・ホール \\
\hline 180-33西武面貨后 大津虞 $(6 \mathrm{~F})$ & & \\
\hline 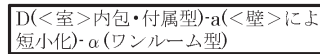 & & 上動線の \\
\hline 建築名 & 竣工复 & \\
\hline \begin{tabular}{l|l}
3 & SH-1(1F) \\
\end{tabular} & & 巨建住宅 \\
\hline \begin{tabular}{l|l}
5 & 住宅No.20(1F) \\
\end{tabular} & 1954 & 巨建住宅 \\
\hline \begin{tabular}{l|l}
$6-2$ & 吉阪祇 $<$ 自邸 $>(2 \mathrm{~F})$ \\
\end{tabular} & 1955 & 正建住宅 \\
\hline 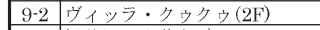 & 1957 & 五建住宅 \\
\hline 12-1 軽井沢の山泳 $(1 \mathrm{~F})$ & 1963 & 巨建住宅 \\
\hline \begin{tabular}{l|l|l|l|l|l|}
$14-1$ & 家 $(1 \mathrm{~F})$ \\
\end{tabular} & 1966 & 巨建住宅 \\
\hline $15-2$ 住宅KAH(2F) & 1967 & 巨建住宅 \\
\hline 22-1 南青山の家 $(1 \mathrm{~F})$ & 1981 & 当建住宅 \\
\hline 64-1 藤枝市立図書馆 $(1 \mathrm{~F})$ & $1979=$ & 公立图書館 \\
\hline 84-1 1 青山タワービル (B1F) & 1969 & 事務所 \\
\hline 89-2 東京海上ビル(基淮階) & 1974 & 事務所 \\
\hline 90-2 山之内製藥本社ビル(基淮階) & 1975 & 事務所 \\
\hline 108-3 掬水亭(基潐階) & 1990 & 旅馆 \\
\hline 108-4 插水亭 $(6 \mathrm{~F})$ & 1990 & 旅館 \\
\hline 111-3 日本芷科大学体育館 $(2 \mathrm{~F})$ & 1970 & 体育錧 \\
\hline 111-4 日本歯科大学体育館 $(3 \mathrm{~F})$ & 1970 & 体育館 \\
\hline 122-3杤木県立美術館 (4F) & 1972 & 美術館 \\
\hline 122-4杤木県立美術館 (5F) & 1972 & 美術館 \\
\hline 145-1神長官守矢資料館 (1F) & 1991 & 博物馆 \\
\hline 149-2 渴博物館 (4F) & 1997 & 博物館 \\
\hline 153-4佐久市庁含(基潍階) & 1975 & 宁含 \\
\hline 182-1紫野 和久傳 (1F) & 1995 & 店舗 \\
\hline 183-1 hhstyle.com(1F) & 2000 & 店舗 \\
\hline 183-3 hhstyle.com(3F) & 2000 & 后赫 \\
\hline 184-6 6 ルイ・ヴィトン表参道 (4F) & 2002 & 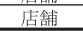 \\
\hline
\end{tabular}

\begin{tabular}{|c|c|c|}
\hline 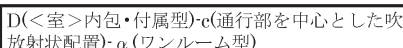 & 计的 & の \\
\hline 建笻名 & 陵工年 & 用途 \\
\hline \begin{tabular}{|l|l|l|l|l|}
$1-1$ & 立体最小限住居(1F) \\
\end{tabular} & 1950 & 进住宅 \\
\hline \begin{tabular}{|l|l|l|l|}
$6-1$ & 古阪取 $<$ 自邸 $>(1 \mathrm{~F})$ \\
\end{tabular} & 1955 & 建住宅 \\
\hline \begin{tabular}{|l|l}
$11-2$ & スカイハウウス $(2 \mathrm{~F})$ \\
\end{tabular} & 1958 & \\
\hline 14-2白の家 $(2 \mathrm{~F})$ & 1966 & 戸建住宅 \\
\hline 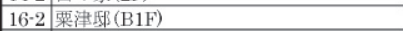 & & \\
\hline 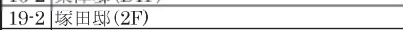 & 1980 & 吾建住宅 \\
\hline \begin{tabular}{|l|l|}
20 & 光格子の家 $(1 \mathrm{~F})$ \\
\end{tabular} & 1980 & 戸建住宅 \\
\hline \begin{tabular}{|l|l|l}
$23-2$ & シルノ゙ーハット $(2 \mathrm{~F})$ \\
\end{tabular} & 1984 & 巨建住宅 \\
\hline \begin{tabular}{|l|l|l|l}
$25-1$ & 小さな家(地階) \\
\end{tabular} & 2000 & F建住宅 \\
\hline \begin{tabular}{|l|l|l}
$25-2$ & 小さな家 $(1 \mathrm{~F})$ \\
\end{tabular} & 2000 & F建住宅 \\
\hline \begin{tabular}{|l|l|}
$25-3$ & 小さな家 $(2 \mathrm{~F})$ \\
\end{tabular} & 2000 & F建住宅 \\
\hline \begin{tabular}{|l|l|}
$29-1$ & 中銀カプセルタワー $(\mathrm{IF})$ \\
\end{tabular} & 1972 & 集合住宅 \\
\hline 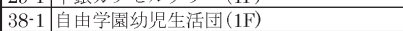 & 1967 & 幼稚園 \\
\hline $38-2$ 自由学園幼児生活団 $(2 \mathrm{~F})$ & $\mid \frac{1906}{1967}$ & 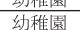 \\
\hline 41-2 板橋さざなふみみ幼稚園アネックス $2(2 \mathrm{~F})$ & 2000 & 幼科隹園 \\
\hline 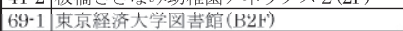 & 1968 & 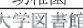 \\
\hline 69-4 東京経济大学因書館(中2F) & 1968 & 大学龱茟伯 \\
\hline $84-3$ 青山タワーピル(基隻階) & 1969 & 事務所 \\
\hline 85-1 余池色素工業本社ピ (IF) & $\mid 1969$ & 事務所 \\
\hline 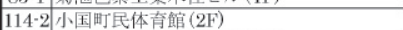 & $\frac{1008}{1988}$ & 体青錧 \\
\hline 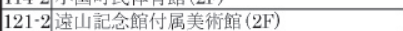 & $\mid \frac{1000}{1970}$ & 美㭪能 \\
\hline 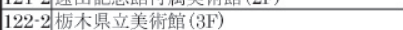 & $\frac{1070}{1972}$ & 美或館 \\
\hline 145-2-2神長官守矢資料館 $(2 \mathrm{~F})$ & $\frac{1012}{1991}$ & 榑物触 \\
\hline 146-3) 八代市立㙛物館·未来の森ミュージアム(3F) & $\frac{1931}{1991}$ & 榑物館 \\
\hline 146-4 八代市立㙛物館·未来的森ミュージア ム (4F) & 1991 & 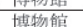 \\
\hline 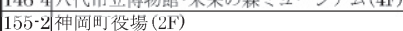 & 1931 & 序量 \\
\hline $162-2$ 和気町中央公民館 $(2 \mathrm{~F})$ & 1070 & 隻会施設 \\
\hline 182-3 政野 和久傅 (3F) & 1995 & 店祴 \\
\hline $183-2$ hhstyle.com $(2 \mathrm{~F})$ & 2000 & 店哺 \\
\hline 184-5 ルル・ヴイトン表参道 $(3 \mathrm{~F})$ & & \\
\hline
\end{tabular}




\begin{tabular}{|c|c|c|c|}
\hline \multicolumn{4}{|c|}{ 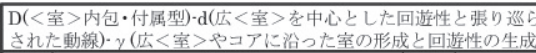 } \\
\hline 番号 & 建筑名 & 形工年 & \\
\hline $41 \cdot 1$ & 板橋さざなみ幼稚園アネックス 2 (1F) & 2000 & 幼稚園 \\
\hline $48 \cdot 3$ & 弘道小学校 $(2 \mathrm{~F})$ & 1991 & 小学校 \\
\hline $60-3$ & 公立はこだて未来大学 $(3 \mathrm{~F})$ & 2000 & 大学 \\
\hline $60-4$ & 公立はこだて未来大学 $(4 \mathrm{~F})$ & 2000 & 大学 \\
\hline $62 \cdot 2$ & 東京都立中央図書館 $(2 \mathrm{~F})$ & 1972 & 大学图書慨 \\
\hline 69-3 & 東京経済大学図書館 $(1 \mathrm{~F})$ & 1968 & 大学图書的 \\
\hline $70-1$ & 芝浦工業大学大宮図書館(地階) & 1971 & 大学图書的 \\
\hline $71 \cdot 1$ & 東北大学付属中央図書館 (B1F) & 1972 & 大学图書的 \\
\hline $71 \cdot 3$ & 東北大学付属中央图書館 $(2 \mathrm{~F})$ & 1972 & 大学图書館 \\
\hline $73 \cdot 2$ & 同志社大学図書館 $(1 \mathrm{~F})$ & 1973 & 大学图書的 \\
\hline $83 \cdot 1$ & 霞が関ビルディング $(2 \mathrm{~F})$ & 1968 & 事務所 \\
\hline $83-2$ & 霞が関ビルディング(基準階) & 1968 & 事務所 \\
\hline $85-2$ & 菊池色素工業本社ピル (基準階) & 1969 & 事務所 \\
\hline $88-2$ & 大同生命本社ビル (基潐階) & 1972 & 事務所 \\
\hline $91 \cdot 2$ & 三井物啇ビル (基淮階) & 1976 & 事務所 \\
\hline $92-3$ & 東京堂千代田ピル $(18 \mathrm{~F})$ & 1977 & 事務所 \\
\hline $100 \cdot 1$ & 群馬ロイヤルホテル $(1 \mathrm{~F})$ & 1975 & ホテル \\
\hline $108-2$ & 掬水亭 $(2 \mathrm{~F})$ & 1990 & 旅馆 \\
\hline $114 \cdot 1$ & 小国町民体育馆 (1F) & 1988 & 体育館 \\
\hline $119 \cdot 1$ & 遊水馆 $(1 \mathrm{~F})$ & 1997 & 㜪技場 \\
\hline $139 \cdot 2$ & 北海道開拓記念馆 $(2 \mathrm{~F})$ & 1971 & 博物館 \\
\hline $149 \cdot 3$ & 潟博物馆 $(5 \mathrm{~F})$ & 1997 & 博物館 \\
\hline $149 \cdot 4$ & 潟博物馆 $(6 \mathrm{~F})$ & 1997 & 博物館 \\
\hline $158 \cdot 3$ & 殖島町役場 $(3 \mathrm{~F})$ & 1983 & 庁舎 \\
\hline $162 \cdot 1$ & 和気町中央公民館 (1F) & 1970 & 集会施設 \\
\hline 166 & 熊本県嘗新澺鹿団地集会所 (1F) & 1993 & 集会施設 \\
\hline $169 \cdot 1$ & 日生劇場 $(1 \mathrm{~F})$ & 1963 & 制劫・ホール \\
\hline $169 \cdot 2$ & 日生劇場 $(2 \mathrm{~F})$ & 1963 & 制場・ホーク \\
\hline $169 \cdot 3$ & 日生劇場 (中 $3 \mathrm{~F}$ ) & 1963 & 制場・ホール \\
\hline $169 \cdot 4$ & 日生劇場 $(3 \mathrm{~F})$ & 1963 & 制堎・ホール \\
\hline $169 \cdot 5$ & 日生劇場 $(4 \mathrm{~F})$ & 1963 & 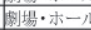 \\
\hline $170 \cdot 1$ & 群馬県民会館 $(1 \mathrm{~F})$ & 1971 & 揦場・ホール \\
\hline $170 \cdot 2$ & 群馬県民会館 $(2 \mathrm{~F})$ & 1971 & 娜場・ホール \\
\hline $175 \cdot 1$ & なんばグランド花月 (B1F) & 1987 & 制場・ホーク \\
\hline $175 \cdot 3$ & なんばグランド花月 $(2 \mathrm{~F})$ & 1987 & 㔊場・ホール \\
\hline $180 \cdot 1$ & 西武百貨店 大津店 $(1 \mathrm{~F})$ & 1976 & 店舗 \\
\hline $180 \cdot 2$ & 西武百货店 大津店 $(4 \mathrm{~F})$ & 1976 & 店赤 \\
\hline
\end{tabular}

$\mathrm{E}$ (中心性をもつく室>群の配置) $-\mathrm{a}(<$ 壁による明確な機能分けと 動線の短小化 $>) \cdot \beta$ (ワンルーム型の<室 $>の$ 連結 \begin{tabular}{|c|c|c|c|}
\hline 建築名 & 陵工年 & 用途 \\
\hline 番号 & \multicolumn{1}{|c|}{1973} & 中学校 \\
\hline $52-1$ & 田野畑中学校 $(1 \mathrm{~F})$ & 197 & \\
\hline
\end{tabular}

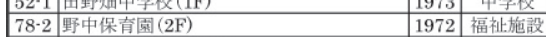

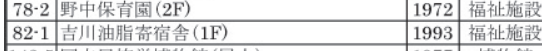

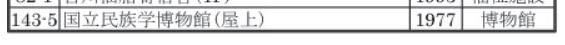

\begin{tabular}{|c|c|c|c|}
\hline \multicolumn{4}{|c|}{$\begin{array}{l}\mathrm{E} \text { (中心性をもつく室〉群の配置) }) \text { (流動的な平面)· } \sigma \text { (凹凸化・伸長化 } \\
\text { した外形に沿った動線の形成) }\end{array}$} \\
\hline 番号 & 建築名 & 摭工年 & 用途 \\
\hline $26-2$ & 晴海高層了パート $(2 \mathrm{~F})$ & 1958 & 集合住宅 \\
\hline $103 \cdot 2$ & 筑波第一ホテル (2F) & 1983 & ホテル \\
\hline $104 \cdot 1$ & ホテル安比グランド(1F) & 1990 & ホテル \\
\hline $124 \cdot 2$ & 群馬県立近代美術館·歴史博物館 (1F) & 1974 & 美術館 \\
\hline $125 \cdot 3$ & 東京都美術館 (1F) & 1975 & 美術館 \\
\hline $159 \cdot 2$ & 神縄県合同庁舎 $(6 \mathrm{~F})$ & 1990 & 宁舎 \\
\hline $177 \cdot 2$ & 東京国際フォーラム $6 \mathrm{~F})$ & 1997 & 㱒場・本 \\
\hline
\end{tabular}

E(中心性老ちつく室〉群の配置)·b(長い軸を有し枝分かれした動線 $\cdot \sigma$ (四凸化・伸長化した外形に沿った動線の形成

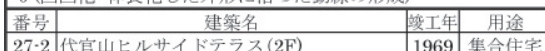

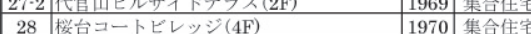

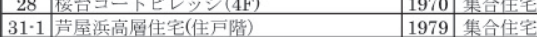
\begin{tabular}{|c|c|c|c|}
\hline 32 & つくば・さくら団地(基潐階) & 1979 & 集合住集合住宅 \\
\hline 3
\end{tabular}

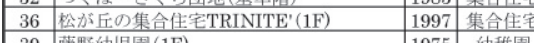
39 藤野幼牢園 $(1 \mathrm{~F})$

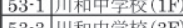

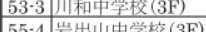

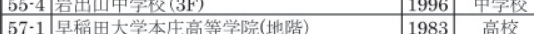

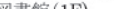

63-3

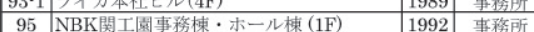

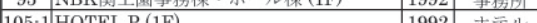
105.2 HOTEL $\mathrm{P}(2 \mathrm{~F})$

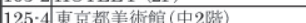
\begin{tabular}{ll|l|l|}
\hline 美術館 \\
\hline $127 \cdot 1$
\end{tabular} \begin{tabular}{|l|l|l|}
\hline $134 \cdot 1$ 奈義町現代美術馆 $(1 F)$ & 1994 & 美術館 \\
\hline
\end{tabular} \begin{tabular}{|l|l|l|}
\hline $137 \cdot 1$ 群馬県立館林美術館 $(1 \mathrm{~F})$ & 2001 & 美術馆 \\
\hline
\end{tabular} $154 \cdot 1$ 和木町庁舎 $(1 \mathrm{~F})$

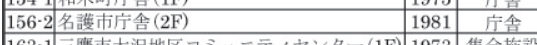
\begin{tabular}{|l|l|l|l|}
\hline $163 \cdot 1$ & 三鷹市大沢地区コミュニティセンター(1F) & 1973 & 集会施設 \\
\hline $163 \cdot 3$ & 三鷕市大沢地区コミュニティセンター(3F) & 1973 & 集会施設 \\
\hline
\end{tabular}

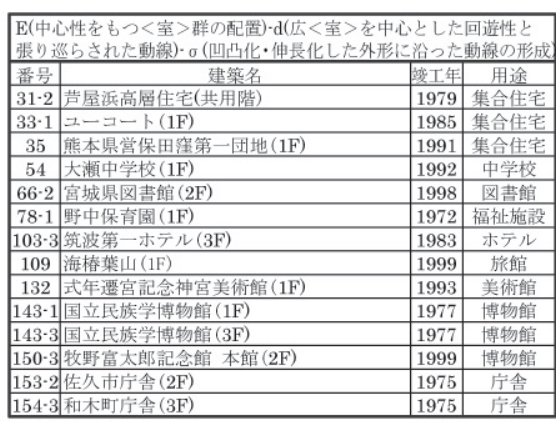

$\mathrm{F}(<$ 室 $>$ 群の連結 $) \cdot \mathrm{a}(<$ 壁 $>$ による明確な機能分け上動線の篮小化 $)$

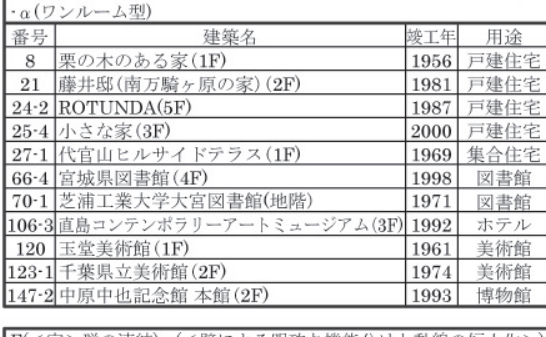

$\mathrm{F}(<$ 室 $>$ 群の連結) $) \cdot \mathrm{a}(<$ 壁による明確な機能分けと動線の短小化 $>)$

\begin{tabular}{l|l}
$-\beta($ ワンルーム型の<室 $>の$ 連結 \\
\hline 悉号
\end{tabular}

\begin{tabular}{|l|l|l|l|}
\hline $44 \cdot 2$ & 真駒内小学校 $(2 \mathrm{~F})$ & 1963 & 小学校 \\
\hline
\end{tabular}

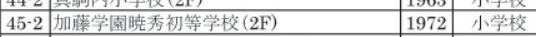

\begin{tabular}{|l|l|l|l|}
\hline $72-4$ & 日本大学生産工学部図書館 $(3 \mathrm{~F})$ & 1973 大学图書館 \\
\hline
\end{tabular}

106-1直島コンテンポラリーアートミュージアム(1F)

$140-2$ 会吉博物舵 $(2 \mathrm{P})$

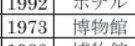

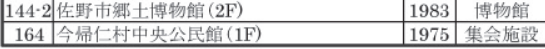

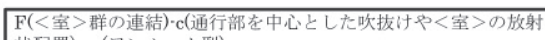

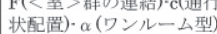

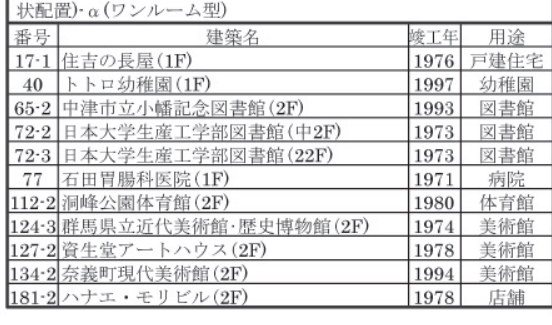

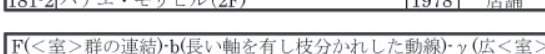

\begin{tabular}{|c|c|c|c|}
\hline 番号 & 建筑名 & 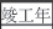 & 用途 \\
\hline 43 & 䬶合保育園(1F) & 2002 & 幼稚園 \\
\hline $62 \cdot 1$ & 東京都立中央図書館 $(1 \mathrm{~F})$ & 1972 & 立园書館 \\
\hline $70 \cdot 4$ & 芝浦工業大学大宫図書館 (3F) & 1971 & 大学図書的 \\
\hline 128 & 土門拳記念馆 $(1 \mathrm{~F})$ & 1983 & 美術館 \\
\hline $150 \cdot 2$ & 牧野富太郎記念館 本館 (1F) & 1999 & 博物館 \\
\hline $152 \cdot 2$ & 萩市庁舎 $(2 \mathrm{~F})$ & 1974 & 庁舎 \\
\hline & 名临市庁舎 $(3 \mathrm{~F})$ & 1981 & 庁舎 \\
\hline
\end{tabular}

$156-3$ 名護市宁舎 $(3 \mathrm{~F})$

$\mathrm{F}$ (<室>群の連結)-d(広く室>を中心とした回遊性と張り巡らさ \begin{tabular}{|l|l|l|l|}
\hline 僠号 & 建筑名 & 用途 \\
\hline
\end{tabular}

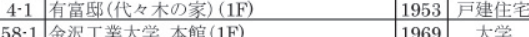

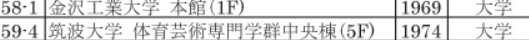

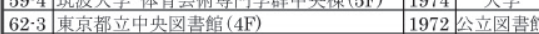

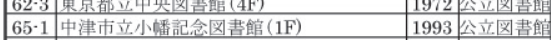

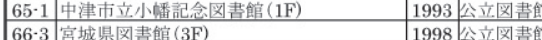

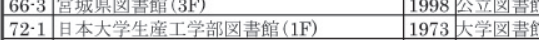

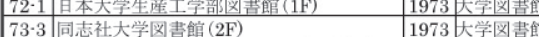

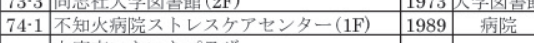

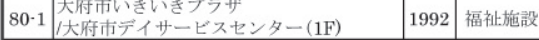
\begin{tabular}{c|l|l|l|}
\hline $80 \cdot 2$ & $\begin{array}{l}\text { 大府市いきいきブラザ } \\
\text { 大府市デイサービスセンター }(2 \mathrm{~F})\end{array} 1992$ & 福祉施設 \\
\hline
\end{tabular}

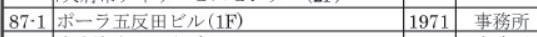
$89 \cdot 1$ 東京海上ビル (1F)

101-2 山の上ホテル $(1 \mathrm{~F})$

113-2 藤沢市秋吉台文化体育館 (1F)

$115-2$ 東京体育馆 $(2 \mathrm{~F})$

$122 \cdot 1$ 杤木県立美術帥 $(1.2 \mathrm{~F})$

130-1 広島市現代美術馆 (B1F)

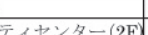

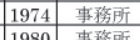
1980 事務所 1984 体育館 1990 体育館 1972 美術館

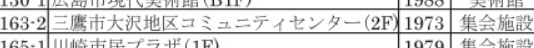
165・1 崎市氏テラクザ(1F) 1979 集会施設

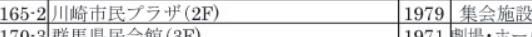
176 清和文楽解 $(1 \mathrm{~F})$

176 消和文果的

$181 \cdot 3$ ハナエ・モリビル $(5 \mathrm{~F})$
$\mathrm{F}$ (<室>群の連結)-d(広く室〉を中心とした回遊性と張り巡ら れた動線) $\cdot \sigma$ (凹凸化・伸長化した外形に沿った重線の形成)

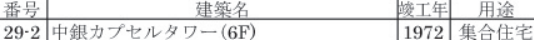

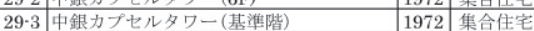
45-1 加藤学園曉秀初等学校 (1F)

$47 \cdot 1$ 城西小学校 $(1 \mathrm{~F})$

$48 \cdot 1$ 弘道小学校(地階)

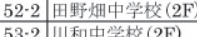

\begin{tabular}{ll}
$53 \cdot 2$ & 川和中学校 $(2 F)$ \\
\hline $55-1$ & 岩出山中学校 (地階)
\end{tabular}

$55-2$ 岩出山中学校 $(1 \mathrm{~F})$

\begin{tabular}{|l|l|l|l}
$55-3$ & 岩出山中学校 $(2 \mathrm{~F})$ \\
\hline $56-2$ & 国際聖マリア学院 (1F) \\
\hline $56-2$ &
\end{tabular}

56-3 $\mid$ 国際聖マリア学院 $(2 \mathrm{~F})$

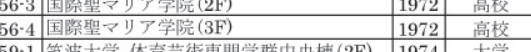

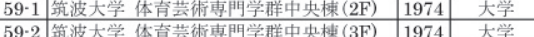

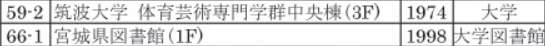
\begin{tabular}{|l|l|l|l|}
\hline $66-1$ & 宫城県図書館(1F) & 1998 & 大学圆書的 \\
\hline $74-2$ & 不知火病院ストレスケアセンター $(2 \mathrm{~F})$ & 1989 & 病院 \\
\hline
\end{tabular} \begin{tabular}{|c|c|c|c|}
\hline 81 & 光風办どり 園 $(1 \mathrm{~F})$ & 1985 & 福祉施設 \\
\hline $90-1$ & 1975 & 事敄所 \\
\hline
\end{tabular}

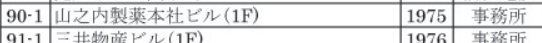

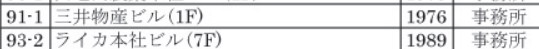
104-2 ホテル安比ク゚ランド $(2 \mathrm{~F})$ \begin{tabular}{|l|c|c|}
\hline $107-1$ 強羅花壇 $(2 \mathrm{~F})$ & 1989 & 旅館 \\
\hline $107-2$ 强羅花壇 $(3 \mathrm{~F})$ & 1989 & 旅館 \\
\hline
\end{tabular} 110-1 国立屋内䌊合競技場·付属体育館(地階) 1964 䪭技場 129 田崎美術館(1F)

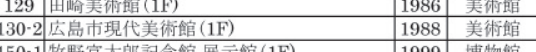

150-1 牧野富太郎記念館 展示館 (1F)

\begin{tabular}{l|l}
$153-3$ & 佐久市庁舎 $(3 \mathrm{~F})$ \\
\hline $154-2$ & 和木町宁全 $(2 \mathrm{~F})$
\end{tabular}

$156-1$ 名護市庁舎 $(1 \mathrm{~F})$

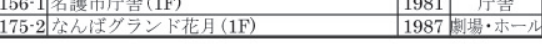

$\mathrm{F}(<$ 室 $>$ 群の連結)·b(長い軸を有し枝分かれした動線) $-\sigma$ (凹凸化・

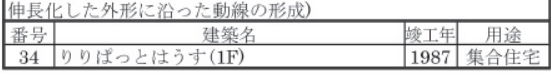

$\mathrm{F}(<$ 室>群の連結)-c(通行部を中心とした吹抜けやく室 $>$ 放射

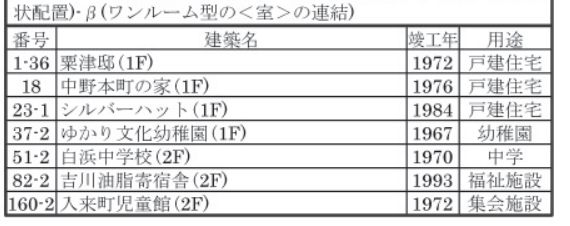

$\mathrm{F}$ (<室>群の連結)·e(流動的な平面構成)・ $\sigma$ (凹凸化・伸長化した 外形に沿った動線の形成)

\begin{tabular}{|c|r|r|c|}
\hline 建筑名 & 蔯工年 & 用途 \\
\hline 75 & 聖路加国際病院(基隻階) & 1992 & 病院 \\
\hline
\end{tabular}

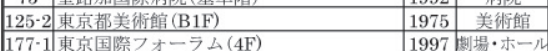
$\mathrm{G}<$ 室 $>$ と<室>の距鹤をとった構成分棟型-a(<壁>による明確 な機能分け上動線の短小化) $\beta$ $\beta$ (ワンルーム型の<室 $>$ の連結 $)$

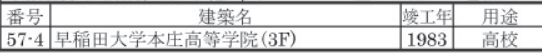

\begin{tabular}{|c|c|c|c|}
\hline \multicolumn{4}{|c|}{ 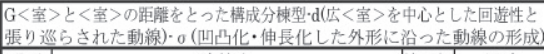 } \\
\hline \begin{tabular}{|l|l} 
番号 \\
\end{tabular} & 建筑名 & 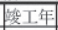 & 用途 \\
\hline $37 \cdot 3$ & ゆかり文化幼稚園 (2F) & 1967 & 幼稚園 \\
\hline $44 \cdot 1$ & 真駒内小学校 (1F) & 1963 & 小学校 \\
\hline \begin{tabular}{|l|l}
$46 \cdot 1$ \\
\end{tabular} & 笠原小学校 (1F) & 1982 & 小学校 \\
\hline $46-2$ & 笠原小学校 $(2 \mathrm{~F})$ & 1982 & 小学校 \\
\hline $47 \cdot 2$ & 城西小学校 $(2 \mathrm{~F})$ & 1987 & 小学校 \\
\hline $48 \cdot 2$ & 弘道小学校 $(1 \mathrm{~F})$ & 1991 & 小学校 \\
\hline 50 & 吉備高原小学校 (1F) & 1998 & 小学校 \\
\hline $51 \cdot 1$ & 白浜中学校 (1F) & 1970 & 中学校 \\
\hline $57 \cdot 3$ & 早稲田大学本左高等学院 (2F) & 1983 & 高校 \\
\hline $107-3$ & 強羅花壇 $(4 \mathrm{~F})$ & 1989 & 旅館 \\
\hline $107 \cdot 4$ & 强羅花壇 $(5 \mathrm{~F})$ & 1989 & 旅館 \\
\hline $123 \cdot 1$ & 千葉県立美術館 & 1974 & 美術館 \\
\hline
\end{tabular}

$\mathrm{G}<$ 室 $>$ とく室 $>$ の距雄をとった構成分棟型·e(流動的な平面構成) - $\sigma$ (凹几化・伸長化した外形汇沿った動線の形成)

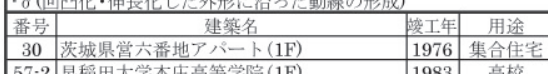

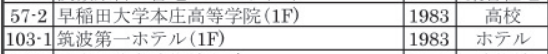
143-2国立民族学博物館 $(2 \mathrm{~F})$ 


\section{7. 結論}

本稿では, 各種建築物の外形, 空間構成, 動線に着目寸ることで, 32 の平面特性を導き出し，その類型に属する事例との関係を探った。 その結果，室を規則的に配置させ，壁により機能が分けられた平面特 性として, 集合住宅と病院に類似性がみられた事が挙げられる。また, ワンルームを壁により明確に機能を分節する平面構成では，規模は異 なるが，平面特性として，戸建住宅や事務所，美術館に類似がみられ た。さらに，大きいく室>やコアを中心に室を配置し，主動線から各 室へと繋がるような動線計画がなされた平面特性をもった用途とし て, 事務所, ホテル, 大学がみられた。このように, 外形, 空間構成, 動線により導き出した 32 の類型は, 現在の一般的に捉えられている ビルディング・タイプにおける用途の枠組みを超えた各種建築物に潜 在的に共通する平面構成の特徵として考えられる。

本稿では, 各種建築物を横断的に捉え, 建築物の外形, 空間構成, 動線の 3 つの視点により導き出された平面特性によって体系化するこ とができた。これにより，建築物を抽象的な機能に置き換えて再構築 寸るという従来のビルディング・タイプが基盤としている観点とは異 なり，建築物を設計する際に必然的に考慮される外形や空間構成，動 線により, 各種建築物を再構築できることを示寸ことができた。また， 建築物における外形, 空間構成, 動線の 3 つの指標により導き出され た平面特性によって, 比較的規模が類似しているという前提ではある が，空間構成を変えることなく用途転換を行なうことが出来る可能性 を示すことができた。今後は，建築物の指標となる外形，空間構成， 動線という観点に，各室の機能や上下階，建築規模をそれぞれ考慮す ることで，さらなる各種建築物の平面特性を明らかにしていく。

\section{謝辞}

本稿を進めるにあたり，山田好美氏には資料，論文作成に当たり多 大な御協力をいただきました。文末ではありますが，ここに記して感 謝申し上げます。

\section{注}

注1）各種建築物の平面特性を比較考察するため, あらゆる用途を網羅し，主に 平面構成に秀でた建築物を掲載している『建築設計資料集成』，日本のジ ヤーナリズムの中でも, 各種建築物が数多く建設され始めた戦後直後から 現在まで継続的に刊行され，毎号特集の傾向が強くなく，史実として建築 物を紹介している『新建築』『建築文化』の計 3 誌に共通して掲載された 作品を平面構成の上でより新たな可能性を示した事実的な作品とみなし 対象作品とする。

注2）各種建築物之呼ばれる建築物は，階数が多くなるものが多く，一つの建築 物でも，階層によっては全く異なる平面特性となっていることも考えられ る。そこで, 各階層を一単位として平面特性を検証していく必要があり, 各対象作品において『建築設計資料集成』に掲載された平面図全てを対象 事例として選定寸る。その結果，185 作品，440 事例が選出された。

注3）曲面部分を含む場合は，一続きであるものは同様に 1 枚とみなし，平面図 から壁と認識できるもののみを扱うため, 壁長が $900 \mathrm{~mm}$ 以下と平面図で 断面が表記されない壁高 $1500 \mathrm{~mm}$ 以下の腰壁等は含まないものとした。

注4）領域が＜壁＞によって完全に閉鎖されず，異なる室用途が連続的に慗がっ ている場合，連結部の長さが $1800 \mathrm{~mm}$ 以上，かつ連続する領域のうち面 積の小さいものを正方形に変形した時, 連結部の長さが正方形の 1 辺長の $1 / 2$ 以上であれば，使用用途上では二つ以上の領域であっても 1 つの室と した。

注5） 1 つの室に対して 2 つ以上の連結部がある際には，それらが対面関係の場 合はそれぞれの連結部の中点を熬ぎ，対面以外の関係では連結部の中点と そこから延ばした垂線の交点を繋ぎ，全ての室の連結部を繋ぐ。(図 5 )

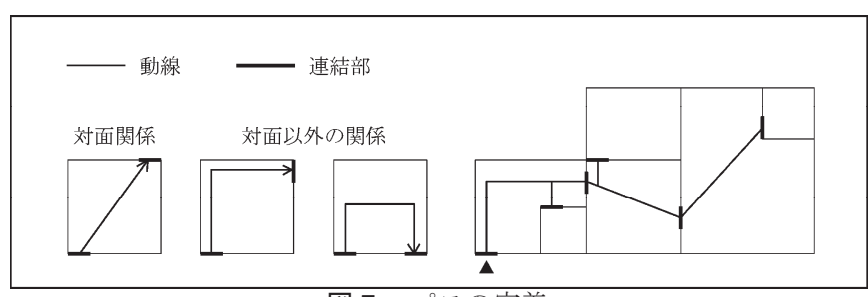

図 5 パスの定義

参考文献

1) 北川啓介，西山尚希：室面積と壁長を考慮した近代住宅作品の平面特性, 日本建築学会計画系論文集, 第 614 号, pp.129-136, 2007.4

2) 山田好美，北川啓介，碓井将義，西山尚希 : 外形と空間構成と動線を考慮 した近代住宅作品の平面特性，日本建築学会計画系論文集，第 629 号， pp.1469-1476, 2008.7

3) 北川啓介, 小田裕司, 坂井愛理 : 各種建築物の専有形式と共有形式, 日本 建築学会計画系論文集，第 637 号，pp.567-576，2009.3

4) 北川啓介, 奥村英里子 : 活動圏を考慮した各種建築物の領域構成, 日本建 築学会計画系論文集，第 651 号, pp.1069-1078，2010.5

5) 小川次郎，坂本一成：公共文化施設における建築の構成とビルディング・ タイプーヴォリュームの複合から見た建築の構成形式に関する研究，日本 建築学会計画系論文集，第 486 号，pp.79-88，1996.8

6) 小川次郎，奥山信一，坂本一成：公共文化施設における形態構成とビルデ イング・タイプーヴオリュームの複合から見た建築の構成形式に関寸る研 究 (2), 日本建築学会計画系論文集, 第 494 号, pp.137-145, 1997.4

7) 小川次郎, 安野 彰, 坂本一成 : 都市型中高層建築のファサードにおける 形態構成ーヴォリュームの複合から見た建築の構成形式に関する研究 (3), 日本建築学会計画系論文集，第 496 号，pp.105-112，1997.6

8) 小川次郎, 迫 慶一郎, 坂本一成 : 現代日本のアトリウム空間をもつ建築 作品の構成一ヴォリュームの複合から見た建築の構成形式に関する研究 (4)，日本建築学会計画系論文集，第 508 号，pp.91-98，1998.6

9) 小川次郎, 坂本一成: 現代日本の都市建築作品における構成形式とビルデ イング・タイプーヴォリュームの複合から見た建築の構成形式に関する研 究 (5)，日本建築学会計画系論文集，第 520 号, pp.189-196，1999.6

10) 中井邦夫, 坂本一成: 現代日本の市庁舎建築における空間構成と用途の分 節一外形ヴォリュームの分節による建築の構成形式に関する研究，日本建 築学会計画系論文集，第 519 号, pp.147-153，1999.5

11) 中井邦夫, 大内靖志, 小川次郎, 坂本一成 : 現代日本の建築作品における 室の集合と外形構成-外形ヴオリュームの分節による建築の構成形式に関 する研究 (2), 日本建築学会計画系論文集, 第 528 号, pp.125-131, 2000.2

12) 中井邦夫, 妹尾慎吾, 坂本一成 : 現代建築作品における架構と空間構成一 外形ヴオリュームの分節による建築の構成形式に関する研究 (3), 日本建 築学会計画系論文集，第 551 号, pp.149-155，2002.1

13）中井邦夫，森山ちはる，坂本一成：現代日本の博物館建築における立地環 境と外形構成-外形ヴォリュームの分節による建築の構成形式に関する研 究 (4), 日本建築学会計画系論文集, 第 607 号, pp.33-40, 2006.9

14) 日本建築学会 : 建築設計資料集成 6 建築一生活，丸善， 1979.10

15) 日本建築学会 : 建築設計資料集成 7 建築一文化，丸善，1981.5

16) 日本建築学会 : 建築設計資料集成 8 建築一産業, 丸善, 1981.9

17）日本建築学会：建築設計資料集成 [総合編]，丸善，2001.6

18）日本建築学会 : 建築設計資料集成 [福祉・医療], 丸善, 2001.9

19) 日本建築学会 : 建築設計資料集成 [集会・市民サービス], 丸善, 2002.9

20) 日本建築学会 : 建築設計資料集成 [教育・図書], 丸善, 2003.3

21）日本建築学会：建築設計資料集成［余暇・宿泊，丸善，2003.3

22）日本建築学会 : 建築設計資料集成 [展示・芸能], 丸善, 2003.9

23）日本建築学会 : 建築設計資料集成 [業務・商業], 丸善, 2004.4

24）日本建築学会：建築設計資料集成 [生産・交通］，丸善，2004.9

25) 日本建築学会 : 第 2 版 コンパクト建築設計資料集成, 丸善， 1994.8

26) 新建築, 新建築社, 1925.7-2005.4

27）建築文化，彰国社，1946.4-2004.12 